\title{
Bedload sediment and nutrient losses in agro-ecosystems of the Brazilian semiarid region
}

\author{
M. A. S. R. Freitas • E. M. Andrade • \\ O. B. Weber • H. A. Q. Palácio • \\ T. O. Ferreira
}

Received: 9 June 2013/Accepted: 27 September 2013/Published online: 12 October 2013

(C) The Author(s) 2013. This article is published with open access at Springerlink.com

\begin{abstract}
The objective of this study was to quantify sediment production from drag, and the loss of organic matter and nutrients as a result of surface runoff in agro-ecosystems of the Brazilian semiarid region. Four watersheds were selected; all located in Iguatu, Ceará state, and characterized by native Caatinga vegetation $(\mathrm{MN})$, thinned vegetation (MR), pasture (PAST), and subsistence agriculture (AGRS). Measurements were taken during the rainy season of 2011. As a result of surface runoff, sediment production by drag (soil drag) ranged from $27.74 \mathrm{~kg} \mathrm{ha}^{-1}$ in AGRS
\end{abstract}

M. A. S. R. Freitas ( $\square)$

Post-Graduate Program-PPGERN, Federal University of Ceará, Fortaleza, Ceará, Brazil

e-mail: masrf@ibest.com.br

E. M. Andrade

Department of Agricultural Engineering, Federal

University of Ceará, Fortaleza, Ceará, Brazil

e-mail: eandrade@pq.cnpq.br

O. B. Weber

Embrapa Tropical Agroindustry, Fortaleza, Ceará, Brazil e-mail: olmar.weber@embrapa.br

H. A. Q. Palácio

Federal Institute of Education, Science and Technology, Iguatu, Ceará, Brazil

e-mail: helbaraujo23@hotmail.com

T. O. Ferreira

Department of Soil Sciences, Federal University of Ceará, Fortaleza, Ceará, Brazil

e-mail: tiago@ufc.br to $580.74 \mathrm{~kg} \mathrm{ha}^{-1}$ in MR. The losses of organic carbon (OC), $\mathrm{Ca}, \mathrm{Mg}, \mathrm{P}$ and $\mathrm{K}$ by sediment drag were higher in the natural ecosystems (MN and MR), and of $\mathrm{Fe}$ and $\mathrm{Zn}$ in the AGRS and PAST agro-ecosystems respectively. The higher erodibility of the Vertisols from the MR, MN and PAST systems, when compared to the Luvisol (AGRS system) resulted in higher sediment production. These results indicate that natural ecosystems of hyper-xerophylic Caatinga vegetation cause an increase sediment production by drag while agro-ecosystems such as PAST and reduced soil tillage on maize, produce an increase in the depth of surface runoff and in the OC levels of the sediment respectively. The loss of nutrients in agroecosystems of semiarid region is governed by the volume of eroded soil with rainfall. The management and conservation of soil and green roofs in watersheds should be taken into account in developing policy and plans for sustainability in the semiarid region.

Keywords Bedload Caatinga .

Hydrossedimentology $\cdot$ Land use $\cdot$ Nutrients

\section{Introduction}

The Caatinga biome is set into the northeastern region of Brazil, and has been intensively exploited for farming in some areas. This biome is predominant, covering the equivalent of $11 \%$ of the area of the country where the vegetation consists of trees that lose 
their leaves during the dry season. It is also one of the semi-arid regions most populous in the world, which, associated with its fragile environment, resulting in a critical scenario for agriculture and human development (Maia et al. 2007). These actions have led to limitations in production, resulting primarily in losses of soil, water and nutrients.

The seasonal and spatial variability of rainfall patterns, with precipitation mainly concentrated from January to May, associated with the erosivity of the rains and with human intervention, have changed the support capacity of the agro-ecosystems in the semiarid region. The high erodibility of Luvisols, Planosols and Leptosols and Regosols, characteristic of the region, may be included as a factor favoring erosion and the degradation of the Caatinga biome (Maia et al. 2007; Giongo et al. 2011).

To this effect, the degradation of the soil and the water of the semiarid region have as its principal cause water erosion (Santos et al. 2007; Díaz et al. 2011). Moreover, the removal of vegetation and frequent slash and burn management in the Caatinga have affected the physical quality of its soils, their nutrient cycle (Wick et al. 2000; Aguiar et al. 2006; Sousa et al. 2012) and also changed the dynamics of the hydrological processes (Santos et al. 2011; Rodrigues et al. 2013). The management of native or cultivated vegetation alters the hydrological response to surface runoff, thereby producing sediment by drag, which results from a complex interaction of hydrological and geological processes (Puigdefabregas et al. 1999; Grimaldi et al. 2004; Owens and Xu 2011) naturally influenced by the geomorphology (Liying et al. 2013) and human actions (Bartley et al. 2006; Moreira et al. 2011). It should be noted that although there are studies on the production and transportation of sediments, mainly for perennial rivers in temperate and humid climates, little is known about the watersediment process that occurs in semiarid regions (Reid et al. 1996; Bautista et al. 2007; Méndez et al. 2010). Due to the potential threat of sediment pollution on downstream areas, there has been a large research effort in recent years to determine the processes controlling water, sediment and nutrient loss in these areas (Bartley et al. 2006; Lobato et al. 2009; Santos et al. 2011; Rodrigues et al. 2013).

During the transportation of sediment, a detrital load is produced in watercourses, resulting from erosive action at the sides and on the bottom of the beds, and known as 'bedload', and a load resulting from detrital removal from the slopes known as 'washload' (Poleto and Merten 2006). As a consequence there are dissolved fractions, particles in suspension and bed material.

Indeed, the quantity and quality of the sediments produced by surface runoff, as well as the associated nutrients, are an important source of knowledge of the dynamics and balance of agro-ecosystems (Fernández et al. 2013) The dragged or transported nutrients may result in the depletion of the soil, and also may lead to the eutrophication of reservoirs (Bertol et al. 2007; Recha et al. 2013).

The objective of this study was to describe sediment production by drag, and quantify the loss of organic matter and nutrients as a result of surface runoff produced by rainfall patterns in different agro-ecosystems in the Brazilian semiarid region.

\section{Materials and methods}

Study area

The study was carried out in areas of Caatinga in the watershed of the Upper Jaguaribe river, in the southcentral region of the state of Ceará, Brazil, which is owned by the Federal Institute of Education, Science and Technology at Iguatu (IFCE-Iguatu Campus). The selected systems are set in four watersheds located between coordinates: $6^{\circ} 23^{\prime} 42^{\prime \prime}-6^{\circ} 23^{\prime} 47^{\prime \prime} \mathrm{S}$ and $39^{\circ} 15^{\prime} 24^{\prime \prime}-39^{\circ} 15^{\prime} 29^{\prime \prime} \mathrm{W}$ (Fig. 1).

Watershed configuration and land use systems

The selected watersheds present courses having ephemeral runoff of the 1st and 2nd Strahler order (Santos et al. 2011). The geomorphic and physiographic features of the watersheds have been described by (Rodrigues et al. 2013), and the main land uses are thinned vegetation (MR), native vegetation (MN), pasture (PAST) and subsistence agriculture (AGRS) (Table 1). For MR, herbaceous plants with a height of over $1.50 \mathrm{~m}$ and a trunk diameter of more than $10 \mathrm{~cm}$ were kept. In the area of PAST, the species Andropogon gayanus Kunt was established (in 2010), being maintained in 2011. In the AGRS maize (Zea mays L.) was grown, adopting a reduced tillage 


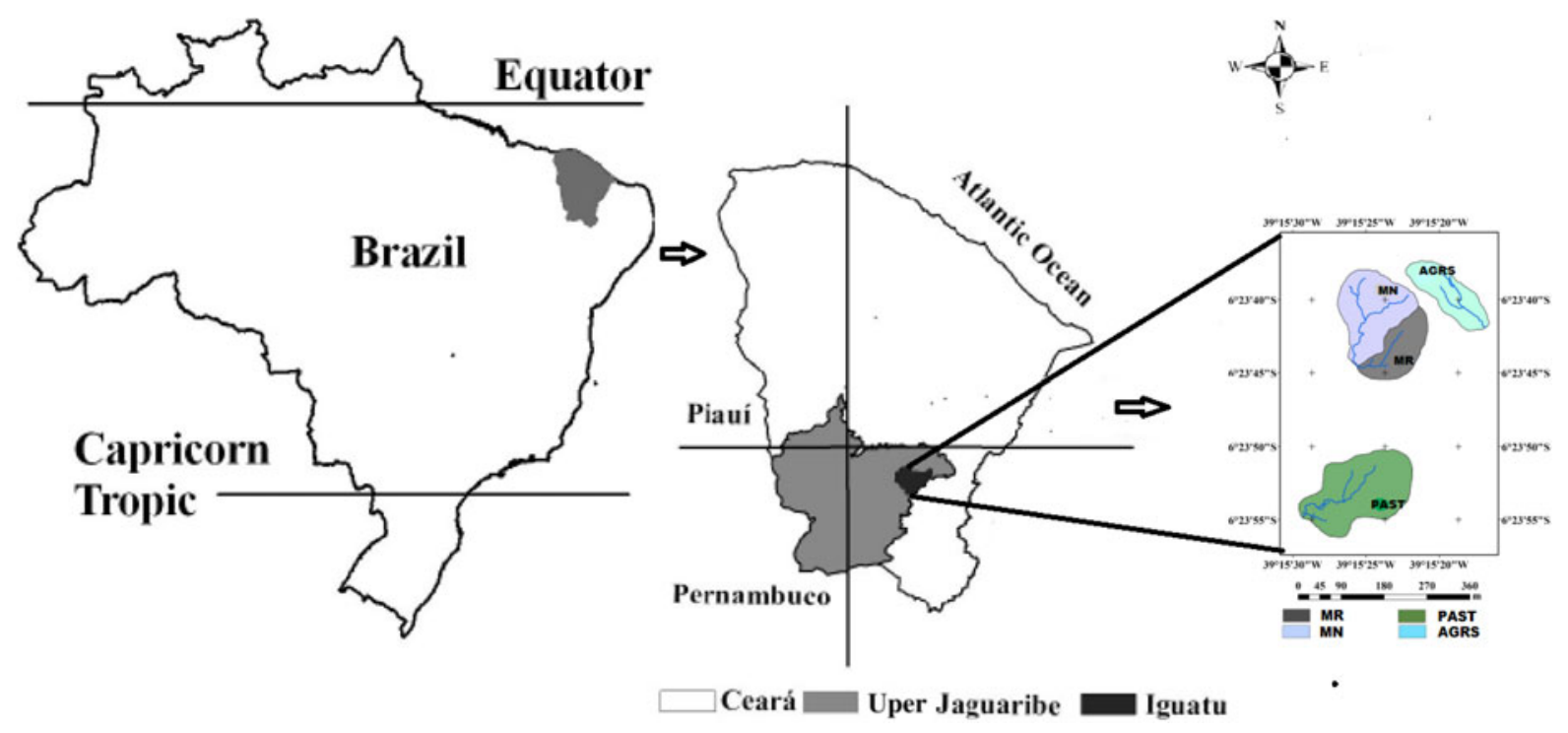

Fig. 1 Location of the study area in the state of Ceará, Brazil

Table 1 Geomorphic and physiographic characteristics of the areas and land use systems in the Iguatu watershed, Ceará, Brazil

\begin{tabular}{|c|c|c|c|c|c|}
\hline \multirow[t]{2}{*}{ Attributes } & \multicolumn{5}{|c|}{ Agro-ecosystems } \\
\hline & MR & $\mathrm{MN}$ & PAST & AGRS & Units \\
\hline $\begin{array}{c}\text { Area of the } \\
\text { basin (A) }\end{array}$ & 1.15 & 2.06 & 2.80 & 1.19 & ha \\
\hline $\begin{array}{l}\text { Length of the } \\
\text { basin }(\mathrm{Cb})\end{array}$ & 188.17 & 204.40 & 253.90 & 208.50 & $\mathrm{~m}$ \\
\hline $\begin{array}{l}\text { Length of the } \\
\text { main course } \\
\text { (Cp) }\end{array}$ & 147.18 & 252.11 & 238.20 & 150.30 & $\mathrm{~m}$ \\
\hline $\begin{array}{l}\text { Slope of the } \\
\text { basin }(\mathrm{Db})\end{array}$ & 8.72 & 10.59 & 5.57 & 10.63 & $\%$ \\
\hline $\begin{array}{l}\text { Shape factor } \\
\text { (Rf) }\end{array}$ & 0.32 & 0.49 & 0.43 & 0.27 & - \\
\hline $\begin{array}{l}\text { Drainage } \\
\text { density (Dd) }\end{array}$ & 153.80 & 192.59 & 146.29 & 209.41 & $\mathrm{~m} \mathrm{ha}^{-1}$ \\
\hline
\end{tabular}

Source: Adapted from Rodrigues et al. (2013)

system of simple rows, with mowing and windrowing of the straw in March 2011.

The vegetation was characterized as scrub and tree closed. In some parts of the study area were observed absence of vegetation or vegetation smaller. In areas of the forest were observed shrub and tree species as Aspidosperma pyrifolium Mart and Crotonsonderianus Muell. Arg., and herbaceous plants as Hyptissauaviolens (L.) point, Hypissp. and Croton SP (Palácio 2011).
It was also the herbaceous developed more intensely in the MR relative to MN. It is noteworthy that the shrub and tree lost leaves during the dry season.

\section{Climate, geology and soils}

In this work, the climate variables (number of events, values precipitation, rainfall intensity and erosivity) were extremely important to characterize the hydrological regime and its variability, as well as be able to relate the effects of vegetation resulting from land use on the blade runoff and sediment production by drag. The classification of soils, geology and defining the textures of watersheds helped in discussions and interpretation of results.

The climate in the region according to the Köppen classification (1948) is BSw'h', hot semiarid, with maximum rainfall between March and May, and average monthly temperatures exceeding $18{ }^{\circ} \mathrm{C}$. Between 1974 and 2008 an average rainfall of $970 \pm 316 \mathrm{~mm}$ and an average potential evaporation of around $1,988 \mathrm{~mm} \mathrm{yr}^{-1}$ were recorded in the study area (Rodrigues et al. 2013).

The soils in the watersheds were classified by Palácio (2011) and, according to WRB-World Reference Base for Soil Resources (2006), corresponded to Calcic Vertisol, typical of MR, MN and PAST; and Calcic Luvisol (Abruptic, Chromic) typical of AGRS.

According to Palácio (2011) the texture of A horizons ranged from silty clay in $\mathrm{MR}$ and $\mathrm{MN}$ 
(137 $\mathrm{g} \mathrm{kg}^{-1}$ sand, $447 \mathrm{~g} \mathrm{~kg}^{-1}$ silt and $416 \mathrm{~g} \mathrm{~kg}^{-1}$ clay), to loam in PAST ( $315 \mathrm{~g} \mathrm{~kg}^{-1}$ sand, $425 \mathrm{~g} \mathrm{~kg}^{-1}$ silt and $260 \mathrm{~g} \mathrm{~kg}^{-1}$ clay) both with type $2: 1$ clay and loamy sand in AGRS (778 $\mathrm{g} \mathrm{kg}^{-1}$ sand, $182 \mathrm{~g} \mathrm{~kg}^{-1}$ silt and $40 \mathrm{~g} \mathrm{~kg}^{-1}$ clay). The clay content in MR, MN and PAST decreased with depth while in AGRS there was a sharp increase in the clay content with depth, characterizing an abrupt textural change (WRBWorld Reference Base for Soil Resources 2006). In the surface layers, acidity, organic carbon (OC) and other chemical characteristics were determined, according to Silva (1999), and the data analysis can be observed on Table 2.

Sampling and analytical determination

Each watershed was equipped with a "Ville de Paris" pluviometer, a Parshall gutter, sediment (bedload) collectors, automatic pluviographs and a data platform (DCP) for obtaining data at $5 \mathrm{~min}$ intervals, as described by Santos et al. (2011). The sediment collecting stations consisted of a trap-type pit (bed load) which was always placed upstream of the gutters to collect sediment from the edges and bottom of the bed after each generating event and it served to quantify sediment production by drag.

The collected sediments were air-dried and analyzed for potential acidity $\left(\mathrm{H}^{+} \mathrm{Al}^{3+}\right)$, organic matter content (by wet oxidation) and nutrients $[\mathrm{P}, \mathrm{K}, \mathrm{Na}, \mathrm{Fe}$,

Table 2 Data from chemical analysis of the surface layer $(0-25 \mathrm{~cm})$ of representative soils from the agro-ecosystems of Iguatu

\begin{tabular}{|c|c|c|c|c|}
\hline \multirow[t]{2}{*}{ Chemical attributes } & \multicolumn{4}{|c|}{ Agro-ecosystems } \\
\hline & MR & $\mathrm{MN}$ & PAST & AGRS \\
\hline $\mathrm{pH}\left(\mathrm{H}_{2} \mathrm{O}\right)$ & 7.39 & 7.74 & 6.77 & 5.68 \\
\hline $\mathrm{H}^{+} \mathrm{Al}^{3+}\left(\mathrm{mmol}_{\mathrm{c}} \mathrm{dm}^{-3}\right)$ & 13.20 & 12.54 & 25.25 & 28.88 \\
\hline $\mathrm{OC}\left(\mathrm{g} \mathrm{kg}^{-1}\right)$ & 17.14 & 19.64 & 28.63 & 11.28 \\
\hline $\mathrm{P}\left(\mathrm{mg} \mathrm{kg}^{-1}\right)$ & 2.15 & 1.88 & 0.99 & 0.99 \\
\hline $\mathrm{Na}\left(\mathrm{mmol}_{\mathrm{c}} \mathrm{dm}^{-3}\right)$ & 1.96 & 1.44 & 5.93 & 0.78 \\
\hline $\mathrm{K}\left(\mathrm{mmol}_{\mathrm{c}} \mathrm{dm}^{-3}\right)$ & 5.55 & 4.09 & 2.76 & 1.71 \\
\hline $\mathrm{Ca}\left(\mathrm{mmol}_{\mathrm{c}} \mathrm{dm}^{-3}\right)$ & 400.84 & 405.02 & 247.39 & 27.26 \\
\hline $\mathrm{Mg}\left(\mathrm{mmol}_{\mathrm{c}} \mathrm{dm}^{-3}\right)$ & 61.02 & 59.93 & 98.86 & 13.40 \\
\hline $\mathrm{Fe}\left(\mathrm{mg} \mathrm{dm}^{-3}\right)$ & 5.51 & 4.19 & 11.16 & 59.97 \\
\hline $\mathrm{Zn}\left(\mathrm{mg} \mathrm{dm}^{-3}\right)$ & 1.46 & 2.30 & 2.62 & 0.75 \\
\hline $\mathrm{Cu}\left(\mathrm{mg} \mathrm{dm}^{-3}\right)$ & 5.15 & 4.40 & 2.48 & 0.83 \\
\hline $\operatorname{Mn}\left(\mathrm{mg} \mathrm{dm}^{-3}\right)$ & 23.10 & 23.52 & 24.15 & 12.50 \\
\hline
\end{tabular}

$\mathrm{Cu}, \mathrm{Mn}$ and $\mathrm{Zn}$ (Mehlich1extractor), $\mathrm{Ca}$ and $\mathrm{Mg}(\mathrm{KCl}$ $1 \mathrm{M}$ extractor)], according to Silva (1999). For the estimation of organic matter and nutrient losses, the sediment production by drag in 57 events and their respective nutrient levels were considered.

Calculation of rainfall erosivity

From the values of the precipitation obtained, and with the spatial variability discarded due to the proximity of the watersheds, the intensity (I) of each event was calculated in $\mathrm{mm} \mathrm{h}^{-1}$ and the maximum intensity in $30 \mathrm{~min}\left(\mathrm{I}_{30}\right)$ in $\mathrm{mm} \mathrm{h}^{-1}$. Using the equation proposed by Wischmeier and Smith (1978), modified by Foster et al. (1981), and quoted by Santos et al. (2007) the kinetic energy (Ec) associated with the precipitation in $\mathrm{MJ} \mathrm{ha}^{-1}$, was obtained as follows:

$E c=0.119+0.0873 \log \mathrm{I}$

where: I-the intensity of the precipitation $\left(\mathrm{mm} \mathrm{h}^{-1}\right)$.

The erosivity of the precipitation $\left(\mathrm{EI}_{30}\right)$ in MJ mm ha ${ }^{-1} \mathrm{~h}^{-1}$ was determined considering the associated kinetic energy (Ec) and the maximum intensity of the precipitation in $30 \mathrm{~min}\left(\mathrm{I}_{30}\right)$, from the equation:

$E I_{30}=\left(\frac{\sum E c * I_{30}}{100}\right)$.

where: Ec — kinetic energy of the precipitation per unit area $\left(\mathrm{MJ} \mathrm{ha}^{-1}\right) ; \mathrm{I}_{30}$-maximum intensity of the precipitation in $30 \mathrm{~min}\left(\mathrm{~mm} \mathrm{~h}^{-1}\right)$.

\section{Statistical analysis}

To identify the soil characteristics that contributed to the discrimination of land use systems, Principal Component Analysis (PCA) was used to identify those with the greatest weight among indicators of the process, i.e. explaining the corresponding percentage of variance (Vialle et al. 2011). To do so, the steps for the standardization (auto-scaling) of the measurements were followed, in order to minimize the effects of different measurement scales generating a zero average and unit variance. A biplot graph of the normalized levels of organic matter and nutrients from sediments (loadings) and of the factors related to the land use systems (scores) was created using the Statistica software (Statsoft Inc. 2007). 


\section{Results and discussion}

Analysis of rainfall in the study area

A total of 57 rainfall events were recorded in the watersheds, with a total of 1,457.29 mm from January to May 2011 (Table 3), which is an atypical rainfall (top $50 \%$ ) for the selectd semiarid region. However, the high rainfall during the study period allowed an assessment of the process of erosion and an estimate sediment production by drag in the different watersheds. Soil erosion has long been recognized as a process closely related to the kinetic energy of rainfall in the form of the erosivity index $\left(\mathrm{EI}_{30}\right)$. (Méndez et al. 2010; Santos et al. 2011).

Three rainfall events ( $>60 \mathrm{~mm}$ ), with high erosivity ( $>800 \mathrm{MJ} \mathrm{mm} \mathrm{ha}^{-1} \mathrm{~h}^{-1}$ ), were recorded at the beginning of the rainy season (January and February). Both values are similar in magnitude to the reported by Méndez et al. (2010) in semiarid Central Mexico. However average rainfall and rainfall intensities $\left(\mathrm{I}_{30}\right)$ were higher in April 2011 (Table 3), when both parameters reached $35 \%$ of the total observed for the year. High rainfall is usually recorded in April in the region, with intensities that may reach $25 \mathrm{~mm} \mathrm{~h}^{-1}$ (Rodrigues et al. 2013). Also, in April we observed the highest erosivity, a fact that influenced sediment production. Similar data were verified by Santos et al. (2007) in a Haplic Luvisol in the semiarid region of Paraíba state. The former found a high monthly dispersion of the precipitation and erosivity, reaching greater values in February and April (53 and $79 \%$ respectively) and with a direct impact on soil erosion. The latter found higher rates of erosivity between

Table 3 Number of events, precipitation values (PPT), maximum rainfall intensity in $30 \mathrm{~min}\left(\mathrm{I}_{30}\right)$ and erosivity $\left(\mathrm{EI}_{30}\right)$ recorded in the rainy season of 2011 in the studied agro-ecosystems of Iguatu

\begin{tabular}{lllll}
\hline Month & Events & $\begin{array}{l}\text { PPT } \\
(\mathrm{mm})\end{array}$ & $\begin{array}{l}\mathrm{I}_{30} \\
\left(\mathrm{~mm} \mathrm{~h}^{-1}\right) \\
\text { Total }\end{array}$ & $\begin{array}{l}\mathrm{EI}_{30} \\
\left(\mathrm{MJ} \mathrm{mm} \mathrm{ha} \mathrm{ho}^{-1} \mathrm{~h}^{-1}\right) \\
\text { Total }\end{array}$ \\
\hline Jan & 13 & 298.50 & 286.62 & $2,325.94$ \\
Feb & 11 & 274.33 & 329.87 & $2,237.62$ \\
Mar & 07 & 92.43 & 139.92 & 652.61 \\
Apr & 17 & 512.19 & 585.12 & $5,112.91$ \\
May & 09 & 279.84 & 272.21 & $2,387.97$ \\
Total & 57 & $1,457.29$ & - & - \\
\hline
\end{tabular}

January and March. The data indicate a high seasonal variability in the distribution of rainfall, with rainfall erosivity in April exceeding by $100 \%$ that registered in the remaining months under evaluation for 2011 (Table 3). According Méndez et al. (2010) and Rodrigues et al. (2013) such characteristics, associated with the spatial variability of the rainfall, are critical in semiarid regions, since there are positive correlations between erosivity and soil erosion and the production of sediment.

Runoff and the production of sediment by drag

The depth of surface runoff and sediment production by drag were higher in April 2011, as a result of the heavy rainfall in that month (Table 4). However, it should be noted that in AGRS, whose soil is classified as a Calcic Luvisol (Abruptic, Chromic), there had already been substantial surface runoff in February which may possibly be related to the presence of the abrupt textural change which may have caused a decrease in the saturated hydraulic conductivity of the soil, favoring surface runoff. In MR, MN and PAST, the cracking of the Vertisol may have contributed to storage of the early precipitation. However, once the soil is wetted and cracks have closed by the expansion of high activity clays (2:1; i.e. smectites), characteristic of those soils, the rate of water infiltration decreases sharply, which may have caused an increase

Table 4 Monthly values of surface runoff and sediment production by drag in the rainy season of 2011 in agro-ecosystems of the semiarid region, Iguatu

\begin{tabular}{llrrrr}
\hline Attributes & Month & \multicolumn{4}{l}{ Agro-ecosystems } \\
\cline { 3 - 6 } & & MR & MN & PAST & AGRS \\
\hline Depth of surface & Jan & 0.63 & 5.71 & 20.33 & 16.40 \\
runoff (mm) & Feb & 15.37 & 38.29 & 49.31 & 72.07 \\
& Mar & 0.00 & 0.38 & 0.00 & 0.10 \\
& Apr & 67.48 & 63.34 & 184.15 & 53.48 \\
& May & 59.69 & 80.14 & 143.57 & 40.87 \\
& Total & 143.15 & 187.87 & 397.36 & 182.93 \\
Sediment & Jan & 1.41 & 0.56 & 3.62 & 0.46 \\
production by & Feb & 178.52 & 84.87 & 73.12 & 11.62 \\
& Mar & 0.08 & 0.08 & 0.31 & 0.20 \\
& Apr ha & 249.12 & 139.75 & 111.21 & 10.87 \\
& May & 151.04 & 117.52 & 70.59 & 4.60 \\
& Total & 580.17 & 342.79 & 258.85 & 27.74 \\
\hline
\end{tabular}


in the depth of surface runoff in these soils (Duiker et al. 2001; Spaargaren 2008).

The total depth of surface runoff in the watersheds was as follows: PAST $>$ MN $>$ AGRS $>$ MR (Table 4), this sequence was recorded for runoff depths per event. This fact can be related to the soil texture, the soil infiltration capacity, (Santos et al. 2007; Méndez et al. 2010) and the geomorphic and physiographic characteristics of the watersheds (Moreira et al. 2011). In the wooded areas (MN and MR) and in PAST, the high clay contents in surface horizons $(>40 \%$, for both MN and MR) and the presence of high activity clays (characteristic of Vertisols) have probably favored surface soil cracking, during dry season, which causes higher initial infiltration rates (Duiker et al. 2001) and also lower surface runoff. However, it is important to note that the $\mathrm{MN}$ watershed presents greater length of the main course, greater slope and greater drainage density in relation to that of MR (Table 1), which may partially explain the different depths of runoff. In AGRS, the initial infiltration is favored by the loamy sandy texture of the superficial horizons.

The ground cover can influence the rate of infiltration of the water (Franco et al. 2002; Santos et al. 2007; Méndez et al. 2010). Thus, the PAST with $A$. gayanus Kunt, being easy to lay and covering the surface of the soil, may have allowed for less water infiltration and higher surface runoff. The low-density drainage and smaller slope of the PAST system (Table 1) did not change the order of surface runoff in systems.

As regards the total volume precipitated, the runoff amounts ranged from $0.10 \%$ in MR to $0.27 \%$ in PAST, which is consistent with values observed in a Luvisol of an agroforestry system in the semiarid region of Ceará, by Aguiar et al. (2006). These authors have obtained $0.04 \%$ in an area with thinned and reduced woody vegetation (silvo-pastoral system) and $0.43 \%$ in an area subjected to the clearing and burning of the woody vegetation, and cultivated with maize and bean (traditional silvo-pastoral system). Santos et al. (2007) on a Stagnic Luvisol (Hyperochric) under hyper-xerophylic Caatinga obtained a surface runoff of $4 \%$ of the total rainfall.

Sediment production can be defined as the transport of material per unit of time and area. In general, a fraction of sediments defined as bedload is little reported, either due to the time and effort needed for its measurement, or to the high spatial and seasonal variability of transport by drag (Reid et al. 1996; Oliveira and Cho 2009). In this study, the following sequence of sediment production by drag was observed: $\mathrm{MR}>\mathrm{MN}>\mathrm{PAST}>\mathrm{AGRS}$. The highest production was evidenced in Vertisols when compared to Luvisols. Due to the higher rainfall, greater intensity and erosivity, the largest sediment production was recorded in April. The sequence demonstrates that hyper-xerophylic Caatinga vegetation is not efficient in dissipating the erosivity or in reducing the impact of rainfall on the disaggregation of surface soil horizons and on the transport of sediment. In forested areas, the raindrops may be retained in the crowns of the trees, forming larger droplets which reach the ground. This fact may results in significant losses of sediments in natural ecosystems, when factors of soil and topography (Liying et al. 2013) favoring the sediment transport on watersheds. The sequence observed for sediment production by drag (Table 4) is consistent with the observations made by Aguiar et al. (2006) who recorded $550 \mathrm{~kg} \mathrm{ha}^{-1}$ in an area of nature reserve, and $110 \mathrm{~kg} \mathrm{ha}^{-1}$ in an area of intensive corn and bean cultivation. Santos et al. (2007), obtained a production by drag of 200 and $300 \mathrm{~kg} \mathrm{ha}^{-1}$ for MN and littered undergrowth respectively also under a Luvisol in the semiarid region of Paraiba state.

In MR and MN, 37 events generating drag sediment were verified, whereas in PAST and AGRS, 42 and 40 were recorded respectively, with 57 being the total of events recorded during the evaluation period in 2011. Reid et al. (1996), determining the production of sediment by drag for a semiarid region in Israel, estimated it to be $8 \%$ of the total sediment produced. Moreover, they noted a high variability in rainfall events, with sediment production by drag not being observed in $37 \%$ of them. This may explain the amounts of sediment yield we observed, and higher sediment production by drag occurred in systems having less events. Similarly, the loamy sand texture of the surface horizon in AGRS may require more energy for transportation when compared the Vertisols (MR, MN and PAST) which present greater erodibility when wet (Duiker et al. 2001; Spaargaren 2008). It should be noted that sediment yield did not exceed $27.74 \mathrm{~kg} \mathrm{ha}^{-1}$ in AGRS (Table 4), even when considering the higher of sediments the systems for slope and drainage density of the watershed (Table 1).

However, we noted the occurrence of water flow on the surface of the soil, and s sediment production by 
drag, which can be related to the soil internal drainage, i.e. with the increase in clay with depth in Luvisols, and with the type of clay in the case of Vertisols. It is noteworthy however, that soil erosion by water is complex and depends on the interactions of several other features such as vegetation cover, soil (preparation, type, moisture, and transport), the slope and size of the watershed, and the intensity and erosivity of the rainfall (Schick et al. 2000; Bartley et al. 2006; Santos et al. 2011). Otherwise, it is important to note that the values of surface runoff and sediment production by drag found here may have been influenced by higher rainfall than in previous years.

\section{Chemical attributes of sediments produced by drag}

The potential acidity and levels of OC and nutrients from sediments produced by drag as a result of the 57 rainfall events, varied between the watersheds (Table 5). In AGRS higher potential acidity of the sediment was found, which resulted in a lower $\mathrm{pH}$ value for the surface layer in this agro-ecosystem. As regards the OC content of sediment production by drag, it was found that the enrichment rate of the OC was higher in AGRS and may be related to the adopted management system: mowing and windrowing of straw for planting maize (Zea mays L.) in 2011.

The high level of phosphorus extractable of sediments collected on forested areas ( $\mathrm{MN}$ and $\mathrm{MR}$ ), where enrichment element rates (sediment per soil) reached up to 180.92 and 150.50 respectively. These high rates may be related to the sampling periods, being made at the end of the rainy season, when possibly phosphorus had been removed from topsoil. Lower rates of phosphorus were observed by Izidorio et al. (2005).

Higher Na levels was observed in sediment from PAST (Table 5), and no enrichment was evidenced in relation to the levels observed in the soil from the watershed (Table 2). Those nutrient levels in the soil may be attributed to the weathering of feldspars and plagioclases, common soils formed from crystalline rocks in semiarid regions.

Considering the sediment production by drag, the agro-ecosystems formed by MN and PAST presented higher levels of $\mathrm{Ca}$ and $\mathrm{Mg}$ respectively. The Vertisols typical of these systems also presented high levels of $\mathrm{Ca}$ and $\mathrm{Mg}$, and that may result in alkalinity of the soil, as they are associated with low levels of $\mathrm{H}^{+} \mathrm{Al}$.

Higher $\mathrm{K}$ and $\mathrm{Mg}$ contend in the sediment from PAST may also be related to plant biomass decaying. Degradation of the plant structure promotes the return of minerals to the topsoil (Wick et al. 2000; Fernández et al. 2013).

In turn, the sediments from drag in AGRS showed high $\mathrm{Fe}, \mathrm{Zn}$ and Mn levels (Table 5), which may be related to mineralogy of the parent material. Considering the different micronutrient levels in the surface

Table 5 Potential acidity, average organic matter and nutrient levels in sediments produced by drag from January to May 2011 in agro-ecosystems of the semiarid region, Iguatu

\begin{tabular}{|c|c|c|c|c|c|}
\hline \multirow[t]{2}{*}{ Nutrients } & \multirow[t]{2}{*}{ Units } & \multicolumn{4}{|l|}{ Agro-ecosystems } \\
\hline & & MR & $\mathrm{MN}$ & PAST & AGRS \\
\hline $\mathrm{H}^{+} \mathrm{Al}^{3+}$ & $\mathrm{mmol}_{\mathrm{c}} \mathrm{dm}^{-3}$ & $4.96 \pm 2.0$ & $6.83 \pm 2.8$ & $4.01 \pm 1.6$ & $40.58 \pm 21.1$ \\
\hline $\mathrm{OC}$ & $\mathrm{g} \mathrm{kg}^{-1}$ & $82.47 \pm 191.9$ & $117.90 \pm 364.6$ & $149.43 \pm 197.3$ & $229.75 \pm 329.0$ \\
\hline $\mathrm{P}$ & $\mathrm{mg} \mathrm{kg}^{-1}$ & $323.58 \pm 85.3$ & $340.13 \pm 83.6$ & $46.27 \pm 8.3$ & $11.70 \pm 7.6$ \\
\hline $\mathrm{Na}^{+}$ & $\mathrm{mmol}_{\mathrm{c}} \mathrm{dm}^{-3}$ & $1.35 \pm 0.3$ & $1.29 \pm 0.5$ & $1.90 \pm 0.8$ & $0.68 \pm 0.4$ \\
\hline $\mathrm{K}^{+}$ & $\mathrm{mmol}_{\mathrm{c}} \mathrm{dm}^{-3}$ & $3.42 \pm 1.0$ & $3.37 \pm 2.6$ & $3.56 \pm 1.8$ & $1.04 \pm 1.0$ \\
\hline $\mathrm{Ca}^{++}$ & $\mathrm{mmol}_{\mathrm{c}} \mathrm{dm}^{-3}$ & $445.36 \pm 126.0$ & $462.27 \pm 113.6$ & $307.91 \pm 103.1$ & $73.27 \pm 36.8$ \\
\hline $\mathrm{Mg}^{++}$ & $\mathrm{mmol}_{\mathrm{c}} \mathrm{dm}^{-3}$ & $121.74 \pm 28.9$ & $116.13 \pm 32.7$ & $138.73 \pm 45.8$ & $37.38 \pm 8.9$ \\
\hline $\mathrm{Fe}$ & $\mathrm{mg} \mathrm{dm} \mathrm{m}^{-3}$ & $0.91 \pm 0.7$ & $1.00 \pm 1.3$ & $9.04 \pm 5.9$ & $134.23 \pm 77.2$ \\
\hline $\mathrm{Zn}$ & $\mathrm{mg} \mathrm{dm} \mathrm{m}^{-3}$ & $0.52 \pm 0.2$ & $0.82 \pm 0.3$ & $1.82 \pm 1.2$ & $3.26 \pm 5.2$ \\
\hline $\mathrm{Cu}$ & $\mathrm{mg} \mathrm{dm}^{-3}$ & $2.05 \pm 1.1$ & $2.03 \pm 1.8$ & $1.67 \pm 0.8$ & $1.32 \pm 1.0$ \\
\hline $\mathrm{Mn}$ & $\mathrm{mg} \mathrm{dm}^{-3}$ & $20.42 \pm 16.7$ & $33.03 \pm 42.6$ & $58.40 \pm 15.0$ & $84.01 \pm 26.0$ \\
\hline
\end{tabular}

Number of samples for: $\mathrm{H}^{+} \mathrm{Al}^{3+}, \mathrm{OC}, \mathrm{P}, \mathrm{Na}^{+}, \mathrm{K}^{+}, \mathrm{Ca}^{++}$and $\mathrm{Mg}^{++}(\mathrm{MR}=23, \mathrm{MN}=21, \mathrm{PAST}=27, \mathrm{AGRS}=16)$; to Fe, $\mathrm{Zn}, \mathrm{Cu}$ and $\mathrm{Mn}[\mathrm{MR}=(8-23) ; \mathrm{MN}=(5-21) ; \mathrm{PAST}=(12-27) ; \mathrm{AGRS}=(7-16)]$ 
layer of AGRS (Table 2), it can be seen that there were increases in content in the sediment produced by drag of 2.2, 4.3 and 6.7 times for $\mathrm{Fe}, \mathrm{Zn}$ and $\mathrm{Mn}$ respectively. In turn, the increase in the $\mathrm{Cu}$ content of the sediment may be due to plant absorption, and the nutrient recycling. A high level of $\mathrm{Cu}$ was detected in sediment production by drag in the forested areas (MN and MR). It is worth pointing out that there is a direct relationship between the nutrient content in eroded soil and that of the surface layer of the watershed (Schick et al. 2000; Bertol et al. 2007).

Nutrient loss in sediments produced by drag

The nutrient losses from sediments produced by drag reached quite significant values, reaching $3.51 \mathrm{~kg} \mathrm{ha}^{-1}$ $\mathrm{Ca}, 0.83 \mathrm{~kg} \mathrm{ha}^{-1} \mathrm{Mg}$ and $0.18 \mathrm{~kg} \mathrm{ha}^{-1} \mathrm{P}$ (Table 6). As for the micronutrients, losses of $5.46 \mathrm{~g} \mathrm{ha}^{-1} \mathrm{Mn}$, $1.59 \mathrm{~g} \mathrm{ha}^{-1} \mathrm{Fe}$, and $0.51 \mathrm{~g} \mathrm{ha}^{-1} \mathrm{Cu}$ were noted. Izidorio et al. (2005) found similar values.

More OC was lost from MR and MN areas a fact that is probably related to the greater erodibility of Vertisols when compared to Luvisols (Duiker et al. 2001) to the density and organic matter content of the surface layer (Schick et al. 2000; Lobato et al. 2009), to the soil management (Franco et al. 2002; Paudel et al. 2012) and to the volume of sediment lost by drag (Fraga and Salcedo 2004).

The macronutrient lose by drag obeyed the decreasing following order: $\mathrm{Ca}>\mathrm{Mg}>\mathrm{P}>\mathrm{K}>\mathrm{Na}$ (Table 6), and a similar sequence occurred in arid ecosystems (Izidorio et al. 2005; Díaz et al. 2011). We inferred that nutrient losses are governed by the volume of eroded soil and to a lesser extent by the levels of elements in the soil.

Losses of $\mathrm{P}$ in the sediment produced by drag exceeded those of $\mathrm{Na}$ and $\mathrm{K}$. Such $\mathrm{P}$ level may be related to its presence of the element in light organic soil particles. Losses of extractable P from sediment produced by drag in forested areas can even be related to its recycling, since the organic $\mathrm{P}$ contend represents up to $65 \%$ of the total detected in the soil, being partly linked to light clay minerals (Cassol et al. 2002). In turn, the $\mathrm{Na}$ and $\mathrm{K}$ are more soluble elements and more weakly adsorbed to soil colloids. Because they are of highly mobile in the soil, it is believed they are lost primarily when in solution. The losses of exchangeable $\mathrm{Na}$ and $\mathrm{K}$ (Table 6) were also influenced by the production of sediment by drag, being higher in thinned and natural forested areas. Aguiar et al. (2006) found more significant losses of $\mathrm{Na}$ and $\mathrm{K}$ from the soil in areas of Caatinga, as well as in the runoff water.

Other exchangeable ions, such as $\mathrm{Ca}^{2+}$ and $\mathrm{Mg}^{2+}$, were detected in high levels in the sediment originating from MR and MN areas, showing similar results to those observed by Izidorio et al. (2005) and by Bertol et al. (2007). According to Wick et al. (2000) the nutrient content of the soil is influenced by the presence of MN. In AGRS, losses of $\mathrm{P}, \mathrm{Na}, \mathrm{K}, \mathrm{Ca}$ and $\mathrm{Mg}$ were probably related to lower sediment production (Table 6), lower watershed soil content (Table 3) and their exportation in the corn field.

The micronutrients losses by drag followed the order $\mathrm{Mn}>\mathrm{Fe}>\mathrm{Cu}>\mathrm{Zn}$ (Table 6); differing from the

Table 6 Loss of organic carbon and nutrients from sediments produced by drag from January to May 2011 in agro-ecosystems of the semiarid region, Iguatu

\begin{tabular}{|c|c|c|c|c|c|}
\hline \multirow[t]{2}{*}{ Nutrients } & \multirow[t]{2}{*}{ Units } & \multicolumn{4}{|l|}{ Agro-ecosystems } \\
\hline & & MR & $\mathrm{MN}$ & PAST & AGRS \\
\hline OC & $\mathrm{kg} \mathrm{ha}^{1}$ & $77.71 \pm 28.6$ & $46.63 \pm 15.9$ & $28.83 \pm 9.6$ & $6.09 \pm 2.4$ \\
\hline$P$ & $\mathrm{~g} \mathrm{ha}^{-1}$ & $182.24 \pm 38.8$ & $114.84 \pm 23.9$ & $11.35 \pm 2.4$ & $0.30 \pm 0.1$ \\
\hline $\mathrm{Na}$ & $\mathrm{g} \mathrm{ha}^{-1}$ & $18.08 \pm 3.8$ & $9.33 \pm 1.9$ & $9.86 \pm 2.0$ & $0.41 \pm 0.1$ \\
\hline K & $\mathrm{g} \mathrm{ha}^{-1}$ & $76.91 \pm 16.5$ & $42.66 \pm 8.5$ & $30.89 \pm 6.3$ & $1.04 \pm 0.3$ \\
\hline $\mathrm{Ca}$ & $\mathrm{g} \mathrm{ha}^{-1}$ & $3,518.66 \pm 1,078.0$ & $1,920.39 \pm 651.6$ & $1,153.89 \pm 355.5$ & $34.02 \pm 9.2$ \\
\hline $\mathrm{Mg}$ & $\mathrm{g} \mathrm{ha}^{-1}$ & $834.08 \pm 175.0$ & $471.17 \pm 99.1$ & $466.52 \pm 94.7$ & $12.18 \pm 2.7$ \\
\hline $\mathrm{Fe}$ & $\mathrm{mg} \mathrm{ha}^{-1}$ & $261.59 \pm 51.3$ & $49.15 \pm 18.2$ & $839.63 \pm 239.0$ & $1,596.12 \pm 411.0$ \\
\hline $\mathrm{Zn}$ & $\mathrm{mg} \mathrm{ha}^{-1}$ & $131.74 \pm 31.8$ & $88.54 \pm 26.6$ & $168.11 \pm 52.1$ & $43.23 \pm 9.5$ \\
\hline $\mathrm{Cu}$ & $\mathrm{mg} \mathrm{ha}^{-1}$ & $516.18 \pm 147.1$ & $273.17 \pm 73.0$ & $135.43 \pm 36.5$ & $7.11 \pm 2.9$ \\
\hline $\mathrm{Mn}$ & $\mathrm{mg} \mathrm{ha}^{-1}$ & $5,036.21 \pm 1,414.2$ & $5,465.24 \pm 1,154.0$ & $5,047.24 \pm 1,337.0$ & $729.90 \pm 306.7$ \\
\hline
\end{tabular}


sequence observed in the soil: $\mathrm{Fe}>\mathrm{Mn}>\mathrm{Cu}>\mathrm{Zn}$ (Table 2). Losses of $\mathrm{Mn}$ and $\mathrm{Cu}$ were certainly influenced by the sediment production (Table 5). In contrast, the loss of $\mathrm{Fe}$ and $\mathrm{Zn}$ was higher in AGRS and PAST, respectively, and it led to suggest distinct behaviors for nutrient loss in agrosystems. Aguiar et al. (2006) found the following order for micronutrient losses: $\mathrm{Fe}>\mathrm{Zn}>\mathrm{Mn}>\mathrm{Cu}$. For the loss of micronutrients, Cassol et al. (2002) partially agreed, but nutrient losses are not directly related to soil and water contends. The interaction of $\mathrm{Zn}$ and $\mathrm{Mn}$ with $\mathrm{OC}$ may cause the formation of organic complexes that can be transported (Tsai et al. 2003).

Multivariate analysis of the principal components of the variables of the sediments allowed biplots building with two loading factors (Fig. 2). These groups formed distinguish the watersheds and land use systems. Component 1 explains $78.68 \%$ of the total variance for MR, MN and PAST with positive values, and with a negative value for AGRS. Component 2, which explains $19.82 \%$ of the total variance, shows positive values for MR, MN and AGRS, and a negative value for PAST. This suggests that the MR, MN and PAST watersheds had similar behavior as regards sediment production, differing from AGRS. Such results are mainly explained by the

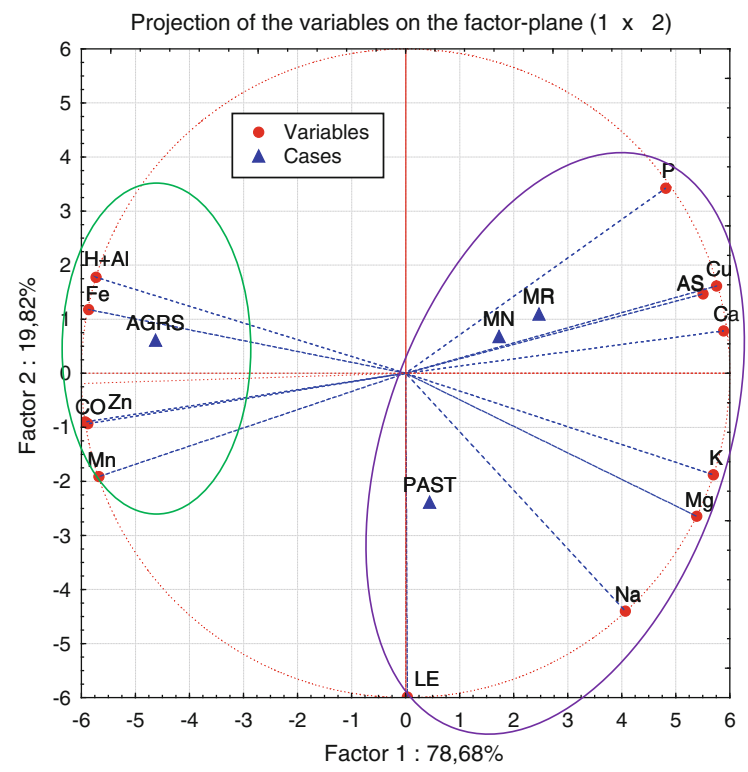

Fig. 2 Analysis of principal components for the chemical properties and sediment losses during the rainy season of 2011 in agro-ecosystems of the semiarid region, Iguatu. ( $L E$ surface runoff, $A S$ sediments produced by drag, $C O$ organic carbon) characteristics of the Vertisols in MR, MN and PAST and of the Luvisol in AGRS.

The variables influenced positively were described by the factor 1 loading for MR, MN and PAST are: K, $\mathrm{Mg}, \mathrm{Na}, \mathrm{Ca}, \mathrm{Cu}, \mathrm{P}$, and runoff depth and sediment loss. AGRS assumed negative value for potential acidity, contends of $\mathrm{Zn}, \mathrm{Mn}, \mathrm{Fe}$ and OC. Differences between variables of the groups identified with circles on Fig. 2, are attributed to edaphic factors, which according to Díaz et al. (2011), are related to the erodibility, soil type, and activity of clays, the presence of abrupt textural change, the silt to clay ratio $(>2)$, cation-exchange capacity, base saturation, OC and nutrient levels in the soil and in the sediments produced by drag. Furthermore, along the axis of loading factor 2 , we observed that positive variables differed the forested areas (MR and $\mathrm{MN}$ ), were the levels of $\mathrm{P}, \mathrm{Cu}, \mathrm{Ca}$ and of sediment loss. In AGRS there was a positive contribution of the potential acidity and Fe content, while levels of OC, $\mathrm{Zn}$ and $\mathrm{Mn}$ negatively affected the differentiation of the sediment. However, the levels of $\mathrm{K}, \mathrm{Mg}$ and $\mathrm{Na}$, and the depth of runoff that were seen in PAST, assumed negative values in Fig. 2. This demonstrates that land use type can be a decisive factor in the levels of these variables in soil (Fraga and Salcedo 2004; Aguiar et al. 2006; Lobato et al. 2009; Sousa et al. 2012) and sediment produced by drag (Vacca et al. 2000; Bartley et al. 2006).

\section{Conclusions}

The greater erodibility of the Vertisols (from forested and grassland areas) in relation to the Luvisol in the system of subsistence farming, promotes higher yields of sediment production by drag, regardless of the vegetation typical of the semiarid region and the traditional systems, and of the number of events that generated surface runoff.

Ecosystems with natural hyper-xerophylic Caatinga vegetation are unable to dissipate the erosivity of the rainfall or avoid greater impact of rain on soil disaggregation and the transported of sediment may affect the sediment production from drag, whereas the systems of PAST and of AGRS with reduced soil tillage, promote increases in the depth of the surface runoff and in the organic matter content of the sediment respectively. 
The loss of nutrients in agro-ecosystems of semiarid region is governed by the volume of eroded soil with rainfall, and the losses follow in descending order: $\mathrm{Ca}>\mathrm{Mg}>\mathrm{P}>\mathrm{K}>\mathrm{Na}>\mathrm{Mn}>\mathrm{Fe}>\mathrm{Cu}>\mathrm{Zn}$.

The management and conservation of soil and green roofs in watersheds should be taken into account in developing policy and plans for sustainability in the semiarid region.

Acknowledgments The authors wish to thank the Federal University of Ceará, (UFC), the Federal Institute of Education, Science and Technology (IFCE-Iguatu), the Brazilian Agricultural Research Corporation and the Research Foundation of Piaui (FAPEPI) for their logistic and financial support.

Open Access This article is distributed under the terms of the Creative Commons Attribution License which permits any use, distribution, and reproduction in any medium, provided the original author(s) and the source are credited.

\section{References}

Aguiar MI, Maia SMF, Oliveira TS, Mendonça ES, Araujo Filho JA (2006) Perdas de solo, água e nutrientes em sistemas agroflorestais no município de Sobral, CE. (Loss of soil, water and nutrients in agroforestry systems in the city of Sobral, CE). Revista Ciência Agronômica 37(3):270-278

Bartley R, Roth CH, Ludwig J, McJannet D, Liedloff A, Corfield J, Hawdon A, Abbott B (2006) Runoff and erosion from Australia's tropical semi-arid rangelands: influence of ground cover for differing space and time scales. Hydrol Process 20:3317-3333

Bautista S, Mayor AG, Bourakhouadar J, Bellot J (2007) Plant spatial pattern predicts hillslope runoff and erosion in a semiarid Mediterranean landscape. Ecosystems 10:987-998

Bertol I, Cogo NP, Schick J, Gudagnin JC, Amaral AJ (2007) Aspectos financeiros relacionados às perdas de nutrientes por erosão hídrica em diferentes sistemas de manejo do solo. (Financial aspects related to nutrient losses by water erosion under different soil management systems). Revista Brasileira de Ciência do Solo 31(1):133-142

Cassol EA, Levien R, Anghinoni I, Badelucci MP (2002) Perdas de nutrientes por erosão em diferentes métodos de melhoramento de pastagem nativa no Rio Grande do Sul (Nutrient losses by erosion in different breeding methods of native pasture in Rio Grande do Sul). Revista Brasileira de Ciência do Solo 26(3):705-712

Díaz FJ, Tejedor M, Jiménez C, Dahlgren RA (2011) Soil fertility dynamics in runoff-capture agriculture, Canary Islands, Spain. Agric Ecosyst Environ 144:253-261

Duiker SW, Flanagan DC, Lal R (2001) Erodibility and infiltration characteristics of five major soils of southwest Spain. Catena 45(2):103-121

Fernández MP, Schnabel S, Lavado-Contador F, Mellado IM, Pérez RO (2013) Soil organic matter of Iberian open woodland rangelands as influenced by vegetation cover and land management. Catena 109:13-24

Foster GR, Mccool DK, Renard KG, Moldenhauer WC (1981) Conservation of the universal soil loss equation the SI metric units. J Soil Water Conserv Baltimore 36:355-359

Fraga VS, Salcedo IH (2004) Declines of organic nutrient pools in tropical semi-arid soils under subsistence farming. Soil Sci Soc Am J 68:215-224

Franco FS, Couto L, Carvalho AF, Jucksch I, Fernandes Filho EI, Meira Neto JAA (2002) Quantificação de erosão em sistemas agroflorestais e convencionais na zona da mata de Minas Gerais. (Quantification of erosion in agroforestry systems and conventional zone of Minas Gerais). Revista Árvore 26(6):751-760

Giongo V, Galvão SRS, Mendes AMS, Gava CAT, Cunha TJF (2011) Soil organic carbon in the Brazilian semiárid tropic. Dyn Soil Dyn Plant Glob Sci Books 5:12-20

Grimaldi C, Grimaldi M, Millet A, Baric T, Boulègue J (2004) Behaviour of chemical solutes during a storm in a rainforested headwater catchment. Hydrol Process 18(1):93-106

Izidorio R, Martins Filho MV, Marques Júnior J, Souza GM, Pereira GT (2005) Perdas de nutrientes por erosão e sua distribuição espacial em área de cana-de-açúcar. (Nutrient losses by erosion and its spatial distribution in the area of cane sugar). Revista Engenharia Agrícola Jaboticabal 25(3):660-670

Liying S, Haiyan F, Deli Q, Junlan L, Qiangguo C (2013) A review on rill erosion process and its influencing factors. Chin Geogr Sci 23(4):389-402

Lobato FAO, Andrade EM, Meieles AC, Santos JCN, Lopes JFB (2009) Perdas de solo e nutrientes em área de Caatinga decorrente de diferentes alturas pluviométricas. (Loss of soil and nutrients in Caatinga area due to different heights rainfall). Revista Agroambiente 3(2):65-71

Maia SMF, Xavier FAS, Oliveira TS, Mendonça ES, Araújo Filho JÁ (2007) Organic carbon pools in a Luvisol under agroforestry and conventional farming systems in the semiarid region of Ceará, Brazil. Agrofor Syst 71:127-138

Méndez RV, Ventura-Ramos E, Oleschko K, HernándezSandoval L, Parrot JF, Nearing MA (2010) Soil erosion and runoff in different vegetation patches from semiarid Central Mexico. Catena 80:162-169

Moreira LFF, Silva FO, Chen S, Andrade HTA, Silva JHT, Righetto AM (2011) Plot-scale experimental studies. Soil Eros Stud 7:151-166

Oliveira F, Cho H (2009) Effect of the spatial variability of land use, soil type, and precipitation on streamflows in small watersheds. J Am Water Resour Assoc 45(3):673-686

Owens PN, Xu Z (2011) Recent advances and future directions in soils and sediments research. J Soils Sediments $11: 875-888$

Palácio HAQ (2011) Avaliação emergética de microbacias hidrográficas do semiárido submetidas a diferentes manejos (Emergy Evaluation of semiarid watersheds under different managements, Dc. Thesis). Tese de Doutorado, Universidade Federal do Ceará, Brasil, p 149

Paudel BR, Udawatta RP, Kremer RJ, Anderson SH (2012) Soil quality indicator responses to row crop, grazed pasture, and agroforestry buffer management. Agrofor Syst 84:311-323

Poleto C, Merten GH (2006) Qualidade dos sedimentos. (Sediment quality) Porto Alegre, ABRH, p 397 
Puigdefabregas J, Sole A, Gutierrez L, Barrio GD, Bôer M (1999) Scales and processes of water and sediment redistribution in drylands: results from the Rambla Honda field site in Southeast Spain. Earth Sci Rev 48:39-70

Recha JW, Lehmann J, Walter MT, Pell A, Verchot L, Johnson M (2013) Stream water nutrient and organic carbon exports from tropical headwater catchments at a soil degradation gradient. Nutr Cycl Agroecosyst 95:145-158

Reid I, Laronne JB, Frostick L (1996) Bed load as component of sediment yield from a semiarid watershed of the northern Negev. Erosion and sediment yield: global and regional perspectives (Proceedings of the exeter symposium, July 1996). IAHS Publ 236:389-397

Rodrigues JO, Andrade EM, Palácio HAQ, Mendonças LAR, Santos JCN (2013) Sediment loss in semiarid small watershed due to the land use. Revista Ciência Agronômica 44(3):488-498

Santos CAG, Silva RM, Srinivasan VM (2007) Análise das perdas de água e solo em diferentes coberturas superficiais no semi-árido da Paraíba (Analysis of soil and water losses in different surface coverage in semiarid region of Paraíba). Revista Okara 1(1):16-32

Santos JCN, Palácio HAQ, Andrade EMA, Meireles ACM, Araújo Neto JR (2011) Runoff and soil and nutrient losses in semiarid uncultivated fields. Revista Ciência Agronômica 42(3):813-820

Schick J, Bertol I, Balbinot Júnior AA, Batistela O (2000) Erosão hídrica em cambissolo húmico alumínico submetido a diferentes sistemas de preparo e cultivo do solo: II. Perdas de nutrientes e carbono orgânico. (Water erosion in Haplumbrept under different tillage systems and soil cultivation: II. Nutrient losses and organic carbon). Revista Brasileira de Ciência do Solo 24(2):437-447
Silva FC (1999) Manual de análises químicas de solos, plantas e fertilizantes/editor técnico. (Manual of chemical analysis of soils, plants and fertilizers/technical editor), 2nd edn. Embrapa Informação Tecnológica, Brasília, DF

Sousa FP, Ferreira TO, Mendonça ES, Romero RE, Oliveira JGB (2012) Carbon and nitrogen in degraded Brazilian semi-arid soils undergoing desertification. Agric Ecosyst Environ 148:11-21

Spaargaren O (2008) Vertisols. In: Chesworth W (ed) Encyclopedia of soil science. Springer, Berlin, pp 807-809

Statsoft Inc (2007) Statistica for Windows. Computer program manual, Tulsa

Tsai LJ, Ho ST, Yu KC (2003) Correlations of extractable heavy metals with organic matters in contaminated river sediments. Water Sci Technol 47(9):101-107

Vacca A, Loddo S, Ollesch G, Puddu R, Serra G, Tomasi D, Aru A (2000) Measurement of runoff and soil erosion in three areas under different land use in Sardinia (Italy). Catena 40:69-92

Vialle C, Sablayrol C, Lovera M, Jacob S, Huau MC, Montrejaud-Vignoles M (2011) Monitoring of water quality from roof runoff: interpretation using multivariate analysis. Water Res 45:3765-3775

Wick B, Tiessen H, Menezes RSC (2000) Land quality changes following the conversion of the natural vegetation into silvopastoral systems in semiarid NE Brazil. Plant Soil 222:59-70

Wischmeier WH, Smith DD (1978) Predicting rainfall erosion losses: a guide to conservation planning. USDA, Agriculture Handbook, Washington, no 537, p 58

WRB-World Reference Base for Soil Resources (2006) World Soil Resources Reports no 103, FAO, Rome, p 133 